\title{
Role of p53 family isoforms in enhancing aggressiveness and chemoresistance in pancreatic cancer (Review)
}

\author{
HOSSEIN JAHEDI, AMINATH LUVEYSA FAHUD and CHOOI LING LIM \\ School of Health Sciences, Department of Applied Biomedical Science and Biotechnology, \\ International Medical University, 126, Jalan Jalil Perkasa 19, Kuala Lumpur 57000, Malaysia
}

Received June 26, 2019; Accepted September 2, 2019

DOI: $10.3892 /$ wasj.2019.23

\begin{abstract}
Pancreatic cancer remains one of the leading causes of cancer-related mortality worldwide. The role of p53 family isoforms in the pathogenesis of human cancer has been under the radar for decades, mainly due to the significant structural homology of p63 and p73 genes with the notorious p53 gene. Both p63 and p73 have two main isoforms, transactivating (TA) and deltaN (DN), each of which has been studied in normal and cancer cells. Although their role in cancer remains elusive and is tissue-specific, the manner in which they act in pancreatic cancer is evident. As for $\mathrm{p} 53$, the mechanism of its gain-of-function activities in pancreatic cancer is now better understood. In this review, the role of each gene and their isoforms is discussed, as well as the possible therapeutic agents for pancreatic cancer. Currently, the science revolving around p53 family isoforms focuses on their specific roles. Thus, we propose that future research be directed at studying the interaction between the isoforms, as well as accelerating the assessment of potential therapeutic agents.
\end{abstract}

\section{Contents}

1. Introduction

2. Structure of p53 family isoforms

3. Role of p53 mutations in pancreatic cancer

4. Role of p63 isoforms in pancreatic cancer

5. Role of $\mathrm{p} 73$ isoforms in pancreatic cancer

6. Therapeutic targets of pancreatic cancer

7. Conclusion and future directions

Correspondence to: Dr Chooi Ling Lim, School of Health Sciences, Department of Applied Biomedical Science and Biotechnology, International Medical University, 126, Jalan Jalil Perkasa 19, Kuala Lumpur 57000, Malaysia

E-mail: chooi_linglim@imu.edu.my

Key words: pancreatic cancer, p53, p63, p73, chemoresistance

\section{Introduction}

Worldwide, pancreatic cancer is the 7 th most common cause of cancer-related mortality, resulting in approximately 432,000 deaths per year, according to the 2018 GLOBOCAN study (1). In Western countries alone, the mortality rate associated with pancreatic cancer is ranked 4 th and is projected to be ranked 2nd by $2030(1,2)$. In the United States, $82 \%$ of pancreatic cancer cases lead to death (3). Among the different types of pancreatic cancers, pancreatic ductal adenocarcinoma (PDAC) encompasses $90-95 \%$ of all cases $(4,5)$. According to the American Cancer Society, a patient with stage IIA pancreatic cancer has a 5-year survival rate of approximately 5\% (6). These statistics indicate an alarming increase in the incidence of and mortality associated with pancreatic cancer. The poor prognosis of patients with pancreatic cancer is due to a number of reasons, including late-stage detection, a lack of sensitive and specific markers, as well as ineffective imaging in the early stages $(4,7)$.

p53 family isoform proteins include p53, p63 and p73, all of which are evolutionarily conserved in humans and other animals. In fact, the origins of p63 seems to go further than the other two proteins (8-10). In cancer research, p53 is known to be the 'guardian of the genome' with anti-proliferative properties that prevent the growth of cancer. In 1997, the discovery of p63 and p73 genes, both of which encode for p53-like sequence specific transcription factors with similar functions, attracted scientists to investigate their role in various types of cancer (11-15).

p63 and p73 have the potential to transactivate target genes of p53, including BAX, NOXA and PUMA, which are responsible for cell death, $\mathrm{p} 21^{\mathrm{WAF} 1}$, responsible for cell cycle arrest and cellular senescence, and 14-3-3o, which is pivotal in cell cycle arrest $(8,12)$. The transactivating (TA) isoforms of p63 and p73 transactivate p53-target genes in response to anti-cancer drugs with pro-apoptotic functions, while the $\mathrm{NH}_{2}$-terminally-truncated deltaN (DN) isoforms exert a dominant-negative behaviour against TA, and hence, are known to be pro-oncogenic (16). It should be noted that p53-dependent cell death requires the assistance of TAp73 and/or TAp63, whereas TAp73/TAp63-dependent cell death following DNA damage occurs without the need for p53 (17).

With their controversial roles in cancer, interest in the p53 family isoforms has intensified over the past decade. Notably, 
research into p53 mutations in PDAC progression has established a platform for exploration of their various interactions with p63 and p73 $(16,17)$. It is becoming increasingly clear that the aggressive and chemoresistant traits of PDAC may not be entirely elucidated by p53-driven mechanisms alone, but may implicate specific isoforms of the p53 family (18-20). Thus, this review discusses the role of the p53 family isoforms in pancreatic cancer, with a perspective on factors conferring cancer aggressiveness and chemoresistance.

\section{Structure of p53 family isoforms}

Structural similarity in proteins can be an indication of the functional similarity of these proteins and p53 family isoforms are no exception $(21,22)$ (Fig. 1). Isoforms of the p53 family have a similar build, with an N-terminal transactivation domain (TAD) together with a proline-rich domain (PR), a central, highly similar DNA-binding domain (DBD), followed by a C-terminal tetramerisation/oligomerisation domain (OD). p63 and p73 contain an additional sterile alpha motif (SAM) domain and a transcription-inhibition domain (TID), which are absent in p53 (23-28). Unlike p53, p63 and p73 exist in distinct functional isoforms, those containing a TAD and those without $(13,28)$. Functionally, TAD seems to be involved in DNA editing and repair pathways, as well as cellular senescence (29); the SAM domain is known to be involved in protein-protein interaction, as well as in the stabilisation of p63 and p73 proteins $(24,29,30)$; thus, it has been suggested that p63 and p73 are more stable than p53 due to the presence of the SAM domain (31).

\section{Role of p53 mutations in pancreatic cancer}

The p53 gene codes for a nuclear transcription factor that responds to genotoxic stress. Strong genotoxic stress activates p53 and promotes cell cycle arrest, cellular senescence and apoptosis, while mild genotoxic stress can activate pathways responsible for repair mechanisms $(17,20,32,33)$. On its own, p53 has 12 different isoforms with similar or unique functions, as a result of alternate splicing, the presence of diverse transcription promoters, as well as multiple translation initiation sites $(32,34,35)$.

In human cancer, p53 inactivation by mutation occurs in $>50 \%$ of cases, and therefore, it is known to be the most common genetic alteration $(36,37)$. These mutations commonly occur within the DBD, resulting in the loss of $\mathrm{p} 53$ functions $(38,39)$. In spite of this, the expression of mutant p53 remains in cancerous cells, which is suggestive of gain-of-function activities. In fact, cancers with the expression of mutant p53 are known to develop more aggressive tumours with an earlier onset, in comparison with cancers that are p53-null $(9,35,40,41)$. The missense mutations, R248H, R273H and R175H, are p53 mutations with the highest frequencies in human cancer $(35,40,42,43)$. Certain mutations result in the loss-of-function of remaining wild-type p53 (dominant-negative effect), while others are known to exert a dominant-negative effect on other tumour suppressors, such as TAp73 (35,44-52).

In pancreatic cancer, p53 is mutated in $75 \%$ of cases (53). Often, p53 mutations can be observed in PDAC, followed by adenosquamous carcinoma of the pancreas (54). In pancreatic neuroendocrine neoplasms, mutant p53 expression is uncommon (55). The sustained expression of mutant p53 seems to be associated with the aggressiveness of pancreatic cancer tumours (56). In the study by Morton et al (2010), mice harbouring pancreatic cancer cells with mutant KRAS and p53 exhibited increased metastases compared to identical mice harbouring the p53-null allele (57).

Mechanisms of p53 gain-of-function mutations. Gain-of-function activities of mutant p53 are responsible for the enhanced tumourigenicity of pancreatic cancer. This was first proven by Wolf et al (1984) through the transfection of mutant p53 into p53-null tumour cells (58). A number of studies have since demonstrated specific p53 gain-of-function activities, such as metabolic changes, migration, promoting cell proliferation, metastasis anti-apoptosis, invasion and angiogenesis (59-62). Studies on MiaPaca-2 pancreatic cancer cell lines, which contain the $\mathrm{R} 273 \mathrm{H}$ mutation of $\mathrm{p} 53$, have demonstrated that this mutation is responsible for increased proliferation, increased colony formation and drug resistance (36,57,63-65). Platelet-derived growth factor receptor $\beta$ (PDGFR $\beta$ ) has been identified as a downstream mediator of mutant p53 in MiaPaca-2 and BxPC-3 pancreatic cancer cell lines, as well as in murine pancreatic cancer models. This PDGFR $\beta$-mutant p53 axis is believed to increase pancreatic cancer cell growth (56). Mutant p53 has also been known to manipulate the pancreatic cell autophagy mechanism, resulting in increased nutrient uptake and a higher growth rate (66).

The mechanisms though which the different p53 hotspot mutations exhibit the gain-of-function properties are diverse. Family isoforms of p53 are structurally similar to p53, particularly in the DNA-binding domain, which allows a p53 target genes to interact with p63 and p73 to mediate responses, such as cell cycle arrest, cellular responses to stress and apoptosis. A subset of p53 hotspot mutations are capable of inactivating p63 and p73 by forming complexes with them. These interactions, which become possible through the conformational changes in the DNA-binding domain of mutant p53, result in gain-of-function properties, such as metastasis, invasion, migration and chemoresistance $(21,48,67)$.

Another mechanism involves physical interaction between mutant p53 and transcription factors, such as NF-Y to mediate target gene expression by altering cell cycle regulation, since the DNA binding sequence of NF-Y is present in the regulatory region of genes involved in the cell cycle (68), as well as interactions with other transcription factors, such as E2F transcription factor 1 (E2F1), vitamin D receptor and nuclear factor (NF)- $\mathrm{B}$ (69). Zhang et al (2013) (62), through their in vivo and in vitro evaluation of mutant p53 knockin mice, discovered that mutant p53 is capable of driving the Warburg effect. This phenomenon is likely driven by the activation of ROCK signalling, which promotes the translocation of GLUT1 to the plasma membrane (62).

Mutant p53 is also known to enhance tumourigenicity and genomic instability by forming complexes with proteins, such as MRE11 (R175H), a DNA nuclease (70), and topoisomerase $1(\mathrm{R} 273 \mathrm{H})$, which is responsible for maintaining DNA topology (71). The mutant p53-ATM complex is responsible for inactivating DNA damage responses and leads to chromosomal translocations and cell cycle arrest (in the case 


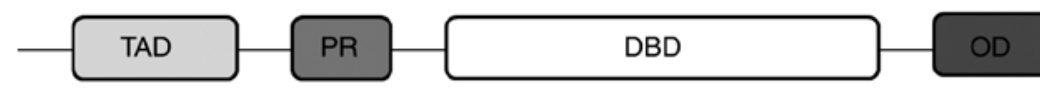

\section{TAp63}

TAp73
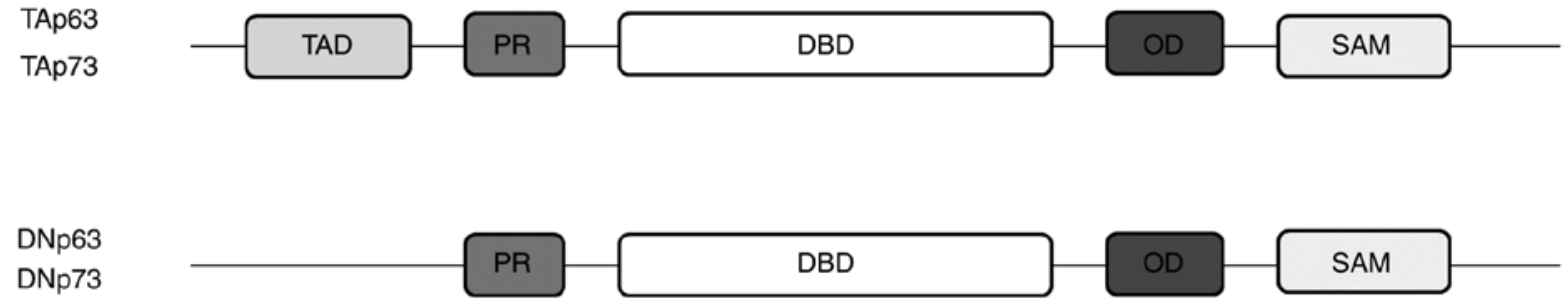

Figure 1. A comparison between genetic structures of p53 family isoforms. TA, transactivating domain; DN, deltaN domain.

of R273H mutation) (72). Brosh and Rotter (2009) demonstrated that mutant p53 is capable of up- or downregulating various genes involved in tumourigenesis, such as $\mathrm{NF}-\kappa \mathrm{B} 2$, vascular endothelial growth factor receptor (VEGFR), Myc, Fos, insulin-like growth factor 2 (IGF2), insulin like growth factor 1 receptor (IGF1R) and early growth response protein 1 (EGR1) (61). This is possible due to the DNA-binding ability of mutant p53 in a DNA structure-selective mode. It has a high affinity for the AT-rich regions and is shown to bind selectively with high affinity B conformation DNA $(73,74)$.

Interaction with miRNA is another mechanism through which mutant p53 exerts its effect, by either inducing or repressing its functions. MicroRNA (miR)-155, which has been shown to repress zinc finger protein 652 (ZNF652), and miR-27a, which has shown to repress EGFR, are both suppressed by mutant p53. Through the repression of EGFR, mutant p53 is capable of stimulating cell proliferation and tumourigenesis by promoting sustained EGFR-induced ERK1/2 activation $(75,76)$. Table I summarises the various mechanisms for mutant p53 gain-of-function.

\section{Role of p63 isoforms in pancreatic cancer}

The p63 protein consists of at least six variants, three of which contain a TA domain, and the remaining without (DN domain) (8). These isoforms regulate a wide range of target genes with opposing regulatory effects. However, their role in cancer remains ambiguous (77). The view that TAp63 is a tumour suppressor, while DNp63 acts as an oncogene is not always applicable $(51,77)$. For instance, the study by Flores et al (2005) concluded that p63 heterogeneity leads to the development of spontaneous tumours (78), while Keyes et al (2006) came to the opposite conclusion (79). The TA and DN isoforms of p63 play various roles in normal cells, as well as in cancerous ones; TAp63 is responsible for glycolysis through liver kinase B1 (LKB1) protein kinase regulation, fatty acid oxidation, insulin secretion, pro-oxidant response, as well as female germ cell preservation (80-84).

In cancer, TAp63 is known to prevent metastases by cell apoptosis and senescence $(51,78)$. Previously, the loss of p63 as a whole was shown to be associated with an accelerated tumour growth and increased invasiveness $(85,86)$. Current research has even extended this finding to prove that it is the loss or inactivation of TAp63 coupled with a p53 mutation, that leads to enhanced tumourigenicity through transforming growth factor (TGF)- $\beta$-induced pathways and the alteration of DNA repair genes (87-89). These findings regarding the function of TAp63 and the consequences of its loss or inactivation have also been proven in pancreatic cancer (88). In fact, TAp63 has a low expression in T3M4, BxPC3, COLO-357, ASPC-1 and PANC-1 pancreatic cancer cell lines, which supports the anticancer properties of TAp63 (18).

The interaction between p63 and p53 plays an important role in cancer progression, and both wild-type p53 and mutant p53 are able to interact with p63 protein (48). Mutant p53 displays a stronger dominant-negative behaviour against TAp63 in comparison with wild-type p53, resulting in the impairment of p63 transactivational target genes $(20,35,49)$. This mechanism has been associated with enhanced cell invasion and metastases in various types of cancer, particularly breast cancer $(87,90,91)$.

The role of DNp63 includes maintaining stem and progenitor cells in stratified and glandular epithelial tissues, as well as glycolysis and antioxidant defence (92-95). As the most abundant p63 isoform, the overexpression of DNp63 in head and neck cancer, non-small cell lung cancer and bladder cancer suggests its tumour survival properties (96-99). In spite of this, there are studies that have demonstrated a low expression of DNp63 in breast and prostate adenocarcinoma, as well as in urothelial carcinoma $(97,100)$. This could indicate the suppressive effect of DNp63 in certain types of cancer, alluding to the paradoxical role of p63. According to Yang et al (2011), DNp63 overexpression is limited to squamous cell carcinoma in which it counteracts p53-mediated tumour suppressive activities (101). In pancreatic cancer, DNp63 is the predominant isoform, with its overexpression being limited to squamous differentiation $(18,102)$. In BxPC-3, COLO-357 and T3M4 pancreatic cancer cell lines, DNp63 expression is elevated, which suggests its cancer-enhancing properties (18).

Runt-related transcription factor 2 (RUNX2) is a nuclear transcription factor generally associated with osteoblast differentiation and bone formation $(103,104)$. In tumours, RUNX2 overexpression has been observed in breast, prostate, gastric cancer and melanoma, as well as in acute myeloid leukaemia (105-110) through target genes responsible for angiogenesis, invasiveness and metastasis, such as VEGF, 
Table I. Mechanisms of major missense hotspot p53 mutations.

\begin{tabular}{|c|c|c|}
\hline Author/(Refs.), year & Mechanism & Examples \\
\hline Liu et al (171), 2014 & Interaction with p53 family isoforms & R248W \\
\hline Stindt et al (172), 2015 & & $\mathrm{R} 175 \mathrm{H}$ \\
\hline Oren and Rotter (52), 2010 & Binding to DNA to alter gene expression & R248W \\
\hline Ludes-Meyers et al (173), 1996 & & $\mathrm{R} 175 \mathrm{H}$ \\
\hline Fiorini et al (69), 2015 & & $\mathrm{R} 273 \mathrm{H}$ \\
\hline \multicolumn{3}{|l|}{ Weisz et al (174), 2004} \\
\hline \multicolumn{3}{|l|}{ Scian et al (175), 2005} \\
\hline Song et al (70), 2007 & Formation of complexes with proteins & $\mathrm{R} 175 \mathrm{H}$ \\
\hline Liu et al (72), 2010 & & $\mathrm{R} 273 \mathrm{H}$ \\
\hline Di Agostino et al (68), 2006 & Binding to transcription factors & $\mathrm{R} 273 \mathrm{H}$ \\
\hline Strano et al (176), 2007 & Regulation of miRNA & $\mathrm{R} 273 \mathrm{H}$ \\
\hline
\end{tabular}

Wang et al (177), 2017

secreted phosphoprotein 1 (Spp1), matrix metalloproteinase (MMP)9 and MMP13 (107,111). As regards pancreatic cancer, Kayed et al discovered the pro-oncogenic role of RUNX2 overexpression and its effect on the tumour microenvironment (109). RUNX2 is responsible for resistance to gemcitabine (GEM) by attenuating p53-dependent cell death, and the silencing of RUNX2 using siRNA has been shown to significantly increase GEM sensitivity, irrespective of the p53 status $(20,112-114)$.

One reason for the strong expression of mutant p53 in pancreatic cancer is the presence of histone deacetylase (HDAC) 1 and 2 (115). Therefore, HDAC inhibitors are under investigation as potential anticancer drugs, of which SAHA, which also affects RUNX2 levels, has recently attracted attention (116,117). MiaPaCa-2, a pancreatic cancer cell line, contains a p53 R248W mutation. As previously demonstrated, upon treatment with SAHA, although the TAp63, $\gamma \mathrm{H} 2 \mathrm{~A}$ histone family member $\mathrm{X}(\gamma \mathrm{H} 2 \mathrm{AX})$, p21, phorbol-12-myristate-13acetate-induced protein 1 (PMAIP1, also known as NOXA) and poly(ADP-ribose) polymerase (PARP) cleavage levels increased, and mutant p53, RUNX and TAp73 were downregulated, the response drug response was relatively poor. However, when p53 was knocked down in MiaPaCa-2 cells, the further downregulation of RUNX2 and upregulation of TAp63 were found to lead to an enhanced sensitivity to SAHA. Similarly, the knockdown of RUNX2 led to the further downregulation of mutant p53 and the upregulation of TAp63 (118). These findings by Ogata et al (118) provide evidence of a regulatory axis involving RUNX2, mutant p53 and TAp63.

RUNX2 knockdown in AsPC-1 p53-null pancreatic cancer cells has been shown to increase GEM sensitivity through TAp-63-dependent cell death pathway activation (113). In PANC-1 pancreatic cancer cells with R273H p53 mutation, RUNX2 depletion mediates TAp63 induction (119). This has been achieved by the exposure of PANC-1 cells to GEM, after which $\gamma \mathrm{H} 2 \mathrm{aX}$ was increased as a sign of DNA damage, and p73 ${ }^{\mathrm{KIP} 1}$ and phosphor-histone $\mathrm{H} 3$ at Ser-10 were reduced as a sign of decreased mitosis. In addition, PARP cleavage was detected at negligible levels. These data suggest that GEM treatment suppresses the cell proliferation rate, but does not effectively promote cell death. At the same time, TAp63 target gene products $\mathrm{p} 21^{\mathrm{WAF} 1}$ and NOXA are upregulated $(119,120)$. Specific to TAp73, the E2F-1 transcriptional activator is also upregulated $(119,121,122)$. Ozaki et al (119) then examined the effect of GEM after mutant p53 was knocked down. The depletion of mutant p53 in pancreatic cancer cell lines with homozygous p53 mutation was not sufficient to enhance the cytotoxic effect of GEM therapy. However, when RUNX2 was knocked down, the cytotoxic effect of GEM was improved in both p53-proficient and deficient pancreatic cancer cells by enhancing TAp63 target genes (p21 $1^{\mathrm{WAF} 1}$ and NOXA), but not through TAp73. This was proved by transfecting PANC-1 cells with TAp63 $\alpha$ plasmids, which exhibited an enhanced cell cycle arrest and/or cell death (119).

miR-301a plays a role in pancreatic cancer hypoxia-induced chemoresistance by targeting p63 and phosphatase and tensin homolog (PTEN) in pancreatic cancer cells $(123,124)$. miR-301a has been reported to be upregulated in pancreatic cancer in comparison with the normal pancreas and/or pancreatitis (125). Therefore, miR-301a has the potential to be an independent prognostic marker for pancreatic cancer (126). In various tumours, hypoxia or low oxygen tension is associated with chemoresistance (127) by the upregulation of hypoxia-inducible factors (HIFs) in tumour cells $(128,129)$. In pancreatic cancer, a few of these factors have been identified, including glucose transporter type 1 (GLUT1), ATP binding cassette subfamily B member 1 (ABCB1) and ATP binding cassette subfamily $\mathrm{G}$ member 2 (ABCG2), all of which are HIF-1 target genes (130-132).

miR-301a expression is increased in an NF- $\kappa \mathrm{B}$-independent manner due to hypoxia. The accumulation of miR-301a leads to a decrease in the TAp63 and PTEN protein levels, and an increase in the phosphorylation of Akt and HIF-1 factors. Notably, the overexpression of TAp63 in hypoxic pancreatic cancer cells leads to reduced cell viability, whereas under normoxic conditions, this effect is not significant. This finding 
is suggestive that a reduction in TAp63 contributes to hypoxiainduced gemcitabine resistance in pancreatic cancer cells. All in all, Luo et al suggested that hypoxia reduced TAp63 and PTEN through the upregulation of miR-301a, which in turn promoted the accumulation of HIF-1a factors and the phosphorylation of Akt, leading to gemcitabine resistance (124).

The ability of DNp63 to regulate cell adhesion in mammary epithelial cells and keratinocytes suggest its role as an oncogene (133). This was also shown in pancreatic cancer by a direct association between $\mathrm{DNp} 63 \alpha$ and $\beta 1$-integrin, an extracellular matrix component that plays a critical role in determining the invasive phenotype of PDAC (134). Upon the upregulation of DNp63 $\alpha$ in PANC-1 cells, increased colony formation and proliferation was observed through an increase in EGFR signalling and its downstream kinases, extracellular-signal-regulated kinase (ERK), Akt and c-Jun N-terminal kinase (JNK) (134). These outcomes, however, have not been consistently evident in other types of pancreatic cancer cells.

\section{Role of p73 isoforms in pancreatic cancer}

Similar to p53, p73 induces apoptosis by transactivating p53-regulated promoters, as well as other p73 target genes, such as p53 upregulated modulator of apoptosis (PUMA), Bax and GRAM domain containing 4 (GRAMD4), which induce apoptosis by acting on the cell mitochondria and cytoplasm $(27,47,135-137)$. Researchers remain divided as to its role in angiogenesis; some studies have suggested that TAp73 exerts a suppressive effect $(138,140)$, whilst others have demonstrated that it is pro-angiogenic (140-142). DNp73 has been constantly shown to be pro-angiogenic (139-142).

As the predominant isoform of $\mathrm{p} 73$, the loss of TAp73 in various cell lines or mouse models has been associated with spontaneous tumour development due to an enhanced genomic instability and the inability of DNA repair mechanisms to be activated $(89,143,144)$. By contrast, a recent study suggested the ability of TAp73 to indirectly induce the expression of interleukin (IL)-1 $\beta$ in lung cancer cell lines, which is suggestive of its tumour-enhancing properties (145). As regards the tumour-suppressive properties of TAp73, a mechanism involving miRNA induction has been identified; these miRNAs, such as miR-3158, inhibit cell migration through epithelial-mesenchymal transition (EMT) and exhibit anti-invasive properties in p53-mutant cancer cell lines $(146,147)$.

In the progression of cancer, the interaction between mutant p53 and p73 plays an important role. Mutant p53 has the ability to co-precipitate and interact with p73, resulting in a dominant-negative effect, which inhibits p73 activities $(47,48)$. It is also clear that certain p53 mutations. such as $\mathrm{R} 175 \mathrm{H}$, which have a high frequency in pancreatic cancer cases (43), exhibit a stronger binding with p73 in comparison with $\mathrm{R} 273 \mathrm{H}$ mutation $(36,48)$.

TGF- $\beta$ plays a tumour suppressive role in pancreatic cancer mediated by SMAD4 (148). The absence of TAp73 disables the SMAD4 dependent TGF- $\beta$ pathway in pancreatic cancer. In the study by Thakur et al (19), TAp73-positive and -negative cell lines were developed from mouse models of pancreatic cancer. In TAp73-deficient cells, which were also p53-null, an increase in EMT markers, such as $\mathrm{N}$-cadherin and vimentin, as well as a reduction in the TGF- $\beta$ inhibitor, biglycan (BGN), and SMAD4, were suggestive of the role of TAp73 in limiting EMT progression (19).

\section{Therapeutic targets of pancreatic cancer}

GEM is a nucleoside analogue and a standard chemotherapeutic drug for pancreatic cancer (149). Although the primary action of GEM is the inhibition of DNA synthesis by the incorporation of gemcitabine diphosphate into DNA (150), it has a secondary effect of activating p53 target genes by binding to DNA and terminating DNA elongation, leading to apoptosis (151-153). GEM itself requires phosphorylation in order to become active and cause cytotoxicity (113). Resistance against GEM is increasing, particularly in pancreatic cancer cell lines with p53 mutation, such as MiaPacCa-2, or cell lines that are null-p53, such as AsPC-1 and cell lines, such as SW1990 that are p53 proficient are yet to exhibit GEM resistance $(20,113,149)$.

Numerous studies have examined mechanisms through which to restore GEM sensitivity in pancreatic cancer. In p53-null pancreatic cancer cell lines, such as AsPC-1, the knockdown and silencing of RUNX2 has been shown to enhance GEM sensitivity through TAp73 and TAp63 pathways which activates p21 and NOXA genes $(20,113)$.

Mouse double minute 2 (MDM2), Itch and neural precursor cell-expressed developmentally downregulated gene 4 (NEDD4) are ubiquitin ligase proteins that are known to suppress p73 in pancreatic cancer $(149,154,155)$, and hence, their expression exhibits enhanced resistance to GEM therapy (156). Targeting these proteins could enhance GEM sensitivity in pancreatic cancer. MI-319 is an siRNA that, in combination with cisplatin, is known to inhibit MDM2 and therefore activate p73 (157). In pancreatic cell lines and xenograft models with p53 mutation, the knockdown of Itch by anti-Itch shRNA transduction coupled with GEM therapy has demonstrated improved sensitivity to GEM (149). Similarly, curcumin and curcumin difluorinated have been identified as an anticancer agents that inhibit NEDD4 and promote p73 activities, and hence improve the response to GEM therapy $(155,158)$. Apart from these three proteins, AKT PI3K protein kinase is known to stabilise mutant p53 protein, and therefore, its inhibition is related to an enhanced effectiveness of cancer therapies (159). Although the effect of AKT/PI3K has not been documented for pancreatic cancer, it is a potential therapeutic target for future research in this area.

Apart from GEM, imatinib, a chemotherapeutic drug most commonly used for chronic myeloid leukaemia, is a potential treatment for pancreatic cancer with mutant p53. It targets the PDGFR $\beta$ pathway, which is constitutively activated by mutant p53 resulting in uncontrollable cell growth (56).

In terms of gene therapy, knocking down the DN isoform of p63 is promising target for pancreatic cancer therapy (18). In a study using mouse models of pancreatic cancer, the shRNA-mediated knockdown of DNp63 was shown to lead to a decrease in tumour volume compared to identical mice carrying non-targeting shRNA (160). Table II summarises the strategies used to inhibit various therapeutic targets in pancreatic cancer. 
Table II. Therapeutic targets that cause resistance to gemcitabine or confer tumour tumour-enhancing properties and strategies to inhibit these targets.

\begin{tabular}{|c|c|c|c|}
\hline Author/(Refs.), year & Therapeutic target & Mechanism of resistance/tumourigenicity & Method of inhibition \\
\hline $\begin{array}{l}\text { Sugimoto et al (113), } 2015 \\
\text { Nakamura et al (20), } 2016\end{array}$ & RUNX2 & Inhibits TAp73 and TAp63 pathways & siRNA-mediated knockdown \\
\hline $\begin{array}{l}\text { Azmi et al (157), } 2010 \\
\text { Yang et al (156), } 2017\end{array}$ & MDM2 & Suppresses p73 pathways & $\begin{array}{l}\text { Inhibition by MI-319 coupled } \\
\text { with cisplatin }\end{array}$ \\
\hline de la Fuente et al (149), 2015 & ITCH & Suppresses p73 pathways & Anti-Itch shRNA knockdown \\
\hline $\begin{array}{l}\text { Azmi et al (158), } 2011 \\
\text { Su et al (155), } 2017\end{array}$ & NEDD4 & Suppresses p73 pathways & $\begin{array}{l}\text { Inhibition by curcumin and } \\
\text { curcumin difluorinated }\end{array}$ \\
\hline Hamilton et al (159), 2014 & AKT PI3K & Stabilises mutant p53 protein & AKT inhibition by MK-2206 \\
\hline Weissmueller et al (56), 2014 & DNp63 & Promotes cell growth & Anti-DNp63 shRNA knockdown \\
\hline $\begin{array}{l}\text { Urist et al (85), } 2002 \\
\text { Bid et al (160), } 2014\end{array}$ & PDGFR $\beta$ & $\begin{array}{l}\text { Activated by mutant p53 and promotes } \\
\text { cell growth }\end{array}$ & Inhibition by imatinib \\
\hline
\end{tabular}

RUNX, runt-related transcription factor 2; MDM2, mouse double minute 2; NEDD4, neural precursor cell-expressed developmentally downregulated gene 4; AKT PI3K, phosphatidylinositol-3-kinase and proteinase kinase B; PDGFR $\beta$, platelet derived growth factor receptor $\beta$.

Table III. drugs involved in p53-mediated therapy for pancreatic cancer.

\begin{tabular}{|c|c|c|c|c|}
\hline Author/(Refs.) & $\begin{array}{l}\text { Drug/small } \\
\text { molecule }\end{array}$ & Mechanism & Method & Clinical stage \\
\hline Vassilev et al (162), 2004 & Nutlin-3a & Inhibits MDM2-p53 pathway & $\begin{array}{l}\text { Binds to MDM2 to block the } \\
\text { MDM2-p53 interaction }\end{array}$ & Preclinical \\
\hline Issaeva et al (164), 2004 & RITA & Inhibits MDM2-p53 pathway & $\begin{array}{l}\text { Binds to p53 to block the } \\
\text { MDM2-p53 interaction }\end{array}$ & Preclinical \\
\hline Bykov et al (168), 2002 & PRIMA-1 & $\begin{array}{l}\text { Restores wild-type function } \\
\text { of p53 }\end{array}$ & $\begin{array}{l}\text { Restores DNA contact and convert } \\
\text { mutant p53 conformation } \\
\text { to wild-type }\end{array}$ & Phase I/II \\
\hline Yu et al (165), 2012 & NSC-319726 & $\begin{array}{l}\text { Restores wild-type function } \\
\text { of p53 }\end{array}$ & $\begin{array}{l}\text { R175H mutation converted to } \\
\text { wild-type }\end{array}$ & Preclinical \\
\hline Tang et al (167), 2007 & CP-31398 & $\begin{array}{l}\text { Restores wild-type function } \\
\text { of p53 }\end{array}$ & $\begin{array}{l}\text { Mutant p53 core domain } \\
\text { stabilisation }\end{array}$ & Preclinical \\
\hline Li et al (169), 2011 & HDAC6 Hsp90 & Degradation of mutant p53 & Interrupts HDAC-p53 interaction & Preclinical \\
\hline
\end{tabular}

MDM2, mouse double minute 2; RITA, reactivation of p53 and induction of tumour cell apoptosis; PRIMA-1, p53 re-activation and induction of massive apoptosis; HDAC6, histone deacetylase 6.

Another promising target for pancreatic cancer is p53-mediated therapy. MDM2, a feedback regulator of p53, is upregulated and frequently amplified in cancers, rendering the MDM2-p53 pathway the optimal target for therapy (161). Several drugs have been formulated to disrupt the p53-MDM2 pathway such as Nutlin-3a, a selective inhibitor of MDM2, designed to block the MDM2-p53 interaction, which can induce cell cycle arrest and apoptosis by blocking the G1 and G2 phases (161-163). In animal models, Nutlin-3a has been demonstrated to induce the activation of p53 signalling, as well as the suppression of tumour growth (161). Another drug,
RITA, is a small molecule that activates the p53 pathway and has successfully demonstrated suppression of tumour growth in animal models (164).

Small molecules, including CP-31398, PRIMA-1 and NSC-319726, can alter mutant p53 to exhibit wild-type p53 functions. PRIMA-1 restores the DNA binding domains by converting the conformation of mutant $\mathrm{p} 53$ (R273H and R175H) to wild-type p53 $(165,166)$. NSC-319726 has been tested to restore the structure and function of wild type p53 in R175H mutations, while CP-31398 stabilises the DNA binding domain of p53, increasing the transcriptional activity $(165,167)$. By 
restoring the wild-type p53 functions, it is enabled to carry out apoptosis and cell cycle arrest (168).

Lastly, the degradation of mutant p53 in PDAC using inhibitory factors, such as HDAC1 and HDAC2 inhibitors, block the HDAC signalling pathway. HDAC and p53 interaction is responsible for stabilising the mutant $\mathrm{p} 53$, rendering it more stable than the wild-type p53 $(115,169,170)$. Table III summarises the p53-mediated therapeutics in pancreatic cancer.

\section{Conclusion and future directions}

The mortality rate of patients with pancreatic cancer continues to increase due to the lack of appropriate screening markers for early detection. As the understanding of biology surrounding the p53 family grows, their role in pathogenesis of cancer may be a target for cancer detection or therapy.

In this review, the structure of p53 family isoforms, and the role of wild-type p53, mutant p53, TAp63, DNp63, TAp73 and DNp73 were discussed. Particularly in pancreatic cancer, it is apparent that in addition to the loss of the apoptotic ability of p53, mutations in this gene leads to gain of cancer-promoting properties through various pathways, such as the inhibition of regulatory genes, promoting growth through the PDGFR $\beta$ pathway, as well as the manipulation of autophagy in cells. As for $\mathrm{p} 63$ and $\mathrm{p} 73$, the function of each isoform forms a paradox as they have contradictory properties in cancer. In actuality, the function of each isoform varies based on the origin of cancer and seems to be tissue-specific.

There is still much to learn about the exact role of p53 family isoforms in cancer. In fact, due to their functional similarity and tissue specificity, how each gene and their isoform interact with each other is particularly attractive for future research. In addition, future research should shift its focus to clinical trials for therapeutic targets such as RUNX2, Itch, MDM2 and DNp63 in order to elucidate more effective strategies for the treatment of pancreatic cancer.

\section{Acknowledgements}

Not applicable.

\section{Funding}

This study was supported by the Fundamental Research Grant Scheme (FRGS/1/2016/SKK08/IMU/03/2) from the Ministry of Education, Malaysia.

\section{Availability of data and materials}

Not applicable.

\section{Authors' contribution}

CLL conceived the study; HJ and ALF acquired and analysed the information and drafted the review; CLL revised it critically for important intellectual content; all authors approved of the version to be published, and are accountable for all aspects of the work. All authors have read and approved the final manuscript.

\section{Ethics approval and consent to participate}

Not applicable.

\section{Patient consent for publication}

Not applicable.

\section{Competing interests}

The authors declare that they have no competing interests.

\section{References}

1. Bray F, Ferlay J, Soerjomataram I, Siegel RL, Torre LA and Jemal A: Global cancer statistics 2018: GLOBOCAN estimates of incidence and mortality worldwide for 36 cancers in 185 countries. CA Cancer J Clin 68: 394-424, 2018.

2. Rahib L, Smith BD, Aizenberg R, Rosenzweig AB, Fleshman JM and Matrisian LM: Projecting cancer incidence and deaths to 2030: The unexpected burden of thyroid, liver, and pancreas cancers in the united states. Cancer Res 74: 2913-2921, 2014.

3. Siegel R, Miller K and Jemal A: Cancer statistics, 2015. CA Cancer J Clin 65: 5-29, 2015.

4. What is pancreatic cancer? The American Cancer Society, Atlanta, GA, 2016. https://www.cancer.org/cancer/pancreatic-cancer/about/what-is-pancreatic-cancer.html. Accessed February 11, 2019.

5. Kleeff J, Korc M, Apte M, La Vecchia C, Johnson CD, Biankin AV, Neale RE, Tempero M, Tuveson DA, Hruban RH and Neoptolemos JP: Pancreatic cancer. Nat Rev Dis Primers 2: $16022,2016$.

6. Survival Rates for Pancreatic Cancer. The American Cancer Society,Atlanta,GA,2016.https://www.cancer.org/cancer/pancreatic-cancer/detection-diagnosis-staging/survival-rates.html. Accessed March 14, 2016.

7. Can pancreatic cancer be found early? The American Cancer Society, Atlanta, GA, 2016. https://www.cancer. org/cancer/pancreatic-cancer/detection-diagnosis-staging/detection.html. Accessed February 11, 2019.

8. Yang A, Kaghad M, Wang Y, Gillett E, Fleming MD, Dötsch V, Andrews NC, Caput D and McKeon F: P63, a P53 homolog at 3Q27-29, encodes multiple products with transactivating, death-inducing, and dominant-negative activities. Mol Cell 2. 305-316, 1998.

9. Hanel W, Marchenko N, Xu S, Yu SX, Weng W and Moll U: Two hot spot mutant p53 mouse models display differential gain of function in tumorigenesis. Cell Death Differ 20: 898-909, 2013.

10. Ferraiuolo M,Di Agostino S, Blandino G and Strano S: Oncogenic intra-p53 family member interactions in human cancers. Front Oncol 6: 77, 2016.

11. Jost C, Marin M and Kaelin W Jr: p73 is a human p53-related protein that can induce apoptosis. Nature 389: 191-194, 1997.

12. Kaghad M, Bonnet H, Yang A, Creancier L, Biscan JC, Valent A, Minty A, Chalon P, Lelias JM, Dumont X, et al: Monoallelically expressed gene related to $\mathrm{p} 53$ at $1 \mathrm{p} 36$, a region frequently deleted in neuroblastoma and other human cancers. Cell 90: 809-819, 1997.

13. Vanbokhoven H, Melino G, Candi E and Declercq W: P63, a story of mice and men. J Invest Dermatol 131: 1196-1207, 2011.

14. Monti P, Russo D, Bocciardi R, Foggetti G, Menichini P, Divizia MT, Lerone M, Graziano C, Wischmeijer A, Viadiu H, et al: EEC- and ADULT-associated TP63 mutations exhibit functional heterogeneity toward $\mathrm{P} 63$ responsive sequences. Hum Mutat 34: 894-904, 2013.

15. Lane DP: Cancer. p53, guardian of the genome. Nature 358: 15-16, 1992.

16. Allocati N, Di Ilio C and De Laurenzi V: p63/p73 in the control of cell cycle and cell death. Exp Cell Res 318: 1285-1290, 2012.

17. Flores ER, Tsai KY, Crowley D, Sengupta S, Yang A, McKeon F and Jacks T: p63 and p73 are required for p53-dependent apoptosis in response to DNA damage. Nature 416: 560-564, 2002 . 
18. Danilov AV, Neupane D, Nagaraja AS, Feofanova EV, Humphries LA, DiRenzo J and Korc M: DeltaNp63alphamediated induction of epidermal growth factor receptor promotes pancreatic cancer cell growth and chemoresistance. PLoS One 6: e26815, 2011.

19. Thakur AK, Nigri J, Lac S, Leca J, Bressy C, Berthezene P, Bartholin L, Chan P, Calvo E, Iovanna JL, et al: TAp73 loss favors Smad-independent TGF- $\beta$ signaling that drives EMT in pancreatic ductal adenocarcinoma. Cell Death Differ 23: 1358-1370, 2016.

20. Nakamura M, Sugimoto H, Ogata T, Hiraoka K, Yoda H, Sang M, Sang M, Zhu Y, Yu M, Shimozato O and Ozaki T: Improvement of gemcitabine sensitivity of p53-mutated pancreatic cancer MiaPaCa- 2 cells by RUNX2 depletion-mediated augmentation of TAp73-dependent cell death. Oncogenesis 5: e233-e233, 2016

21. Levrero M, De Laurenzi V, Costanzo A, Gong J, Wang JY and Melino G: The p53/p63/p73 family of transcription factors: Overlapping and distinct functions. J Cell Sci 113: 1661-1670, 2000

22. Murray-Zmijewski F, Lane DP and Bourdon JC: p53/p63/p73 isoforms: An orchestra of isoforms to harmonise cell differentiation and response to stress. Cell Death Differ 13: 962-972, 2006.

23. Enthart A, Klein C, Dehner A, Coles M, Gemmecker G, Kessler H and Hagn F: Solution structure and binding specificity of the p63 DNA binding domain. Sci Rep 6: 26707, 2016.

24. Chen TH, Wu YJ, Hou JN, Chiu CH and Chen WJ: The p53 gene with emphasis on its paralogues in mosquitoes. J Microbio Immunol Infect 50: 747-754, 2017.

25. Heering J, Jonker HR, Löhr F, Schwalbe H and Dötsch V: Structural investigations of the p53/p73 homologs from the tunicate species Ciona intestinalis reveal the sequence requirements for the formation of a tetramerization domain. Protein Sci 25 410-422, 2016

26. Dos Santos HG, Nunez-Castilla J and Siltberg-Liberles J: Functional diversification after gene duplication: Paralog specific regions of structural disorder and phosphorylation in p53, p63, and p73. PLoS One 11: e0151961, 2016.

27. Yoon MK, Ha JH, Lee MS and Chi SW: Structure and apoptotic function of p73. BMB Rep 48: 81-90, 2015

28. Shin JS, Ha JH, Lee DH, Ryu KS, Bae KH, Park BC, Park SG, Yi GS and Chi SW: Structural convergence of unstructured p53 family transactivation domains in MDM2 recognition. Cell Cycle 14: 533-543, 2015.

29. Walker CW, Van Beneden RJ, Muttray AF, Böttger SA, Kelley ML, Tucker AE and Thomas WK: P53 superfamily proteins in marine bivalve cancer and stress biology. Adv Mar Biol 59: 1-36, 2011.

30. Neira JL and Cámara-Artigas A: Trifluoroethanol-induced conformational transition of the C-terminal sterile alpha motif (SAM) of human p73. Arch Biochem Biophys 619: 1-9, 2017.

31. Brandt T, Kaar JL, Fersht AR and Veprintsev DB: Stability of p53 homologs. PLoS One 7: e47889, 2012.

32. Swiatkowska A, Żydowicz P, Sroka J and Ciesiołka J: The role of the 5 ' terminal region of p53 mRNA in the p53 gene expression. Acta Biochim Pol 63: 645-651, 2016.

33. Vousden KH and Prives C: Blinded by the light: The growing complexity of p53. Cell 137: 413-431, 2009.

34. Luh LM, Kehrloesser S, Deutsch GB, Gebel J, Coutandin D, Schäfer B, Agostini M, Melino G and Dötsch V: Analysis of the oligomeric state and transactivation potential of TAp73 $\alpha$. Cell Death Differ 20: 1008-1016, 2013.

35. Billant O, Léon A, Le Guellec S, Friocourt G, Blondel M and Voisset C: The dominant-negative interplay between p53, p63 and p73: A family affair. Oncotarget 7: 69549-69564, 2016.

36. Muller PA and Vousden KH: P53 mutations in cancer. Nat Cell Biol 15: 2-8, 2013

37. Kandoth C, McLellan MD, Vandin F, Ye K, Niu B, Lu C, Xie M, Zhang Q, McMichael JF, Wyczalkowski MA, et al: Mutational landscape and significance across 12 major cancer types. Nature 503: 333-339, 2013

38. Joerger AC and Fersht AR: Structural biology of the tumor suppressor p53 and cancer-associated mutants. Adv Cancer Res 97: 1-23, 2007.

39. Leroy B, Fournier JL, Ishioka C, Monti P, Inga A, Fronza G and Soussi T: The TP53 website: An integrative resource centre for the TP53 mutation database and TP53 mutant analysis. Nucleic Acids Res 41 (Database issue): D962-D969, 2013.

40. Petitjean A, Mathe E, Kato S, Ishioka C, Tavtigian SV, Hainaut $P$ and Olivier M: Impact of mutant p53 functional properties on TP53 mutation patterns and tumor phenotype: Lessons from recent developments in the IARC TP53 database. Hum Mutat 28: 622-629, 2007.
41. Zerdoumi Y, Aury-Landas J, Bonaïti-Pellié C, Derambure C, Sesboüé R, Renaux-Petel M, Frebourg T, Bougeard G and Flaman JM: Drastic effect of germline TP53 missense mutations in Li-Fraumeni patients. Hum Mutat 34: 453-461, 2013.

42. Olivier M, Hollstein M and Hainaut P: TP53 mutations in human cancers: Origins, consequences, and clinical use. Cold Spring Harb Perspect Biol 2: a001008, 2010.

43. Lehmann BD, Ding Y, Viox DJ, Jiang M, Zheng Y, Liao W, Chen X, Xiang W and Yi Y: Evaluation of public cancer datasets and signatures identifies TP53 mutant signatures with robust prognostic and predictive value. BMC Cancer 15: 179, 2015.

44. Inga A, Cresta S, Monti P, Aprile A, Scott G, Abbondandolo A, Iggo R and Fronza G: Simple identification of dominant p53 mutants by a yeast functional assay. Carcinogenesis 18: 2019-2021, 1997

45. Monti P, Campomenosi P, Ciribilli $\mathrm{Y}$, Iannone R, Inga A, Abbondandolo A, Resnick MA and Fronza G: Tumour p53 mutations exhibit promoter selective dominance over wild type $\mathrm{p} 53$. Oncogene 21: 1641-1648, 2002

46. Monti P, Perfumo C, Bisio A, Ciribilli Y, Menichini P, Russo D, Umbach DM, Resnick MA, Inga A and Fronza G: Dominant-negative features of mutant p53 in germline carriers have limited impact on cancer outcomes. Mol Cancer Res 9: 271-279, 2011.

47. Di Como CJ, Gaiddon C and Prives C: p73 function is inhibited by tumor- derived p53 mutants in mammalian cells. Mol Cell Biol 19: 1438-1449, 1999.

48. Gaiddon C, Lokshin M, Ahn J, Zhang T and Prives C: A subset of tumor-derived mutant forms of p53 down-regulate p63 and p73 through a direct interaction with the p53 core domain. Mol Cell Biol 21: 1874-1887, 2001.

49. Strano S, Fontemaggi G, Costanzo A, Rizzo MG, Monti O, Baccarini A, Del Sal G, Levrero M, Sacchi A, Oren M and Blandino G: Physical interaction with human tumor-derived p53 mutants inhibits p63 activities. J Biol Chem 277: 18817-18826, 2002.

50. Monti P, Campomenosi P, Ciribilli Y, Iannone R, Aprile A, Inga A, Tada M, Menichini P, Abbondandolo A and Fronza G: Characterization of the p53 mutants ability to inhibit p73 beta transactivation using a yeast-based functional assay. Oncogene 22: 5252-5260, 2003.

51. Melino G: P63 is a suppressor of tumorigenesis and metastasis interacting with mutant P53. Cell Death Differ 18: 1487-1499, 2011.

52. Oren M and Rotter V: Mutant p53 gain-of-function in cancer. Cold Spring Harbor perspectives in biology 2: a001107, 2010.

53. Li DH, Xie KP, Wolff R and Abbruzzese JL: Pancreatic cancer. Lancet 363: 1049-1057, 2004

54. Brody JR, Costantino CL, Potoczek M, Cozzitorto J, McCue P, Yeo CJ, Hruban RH and Witkiewicz AK: Adenosquamous carcinoma of the pancreas harbors KRAS2, DPC4 and TP53 molecular alterations similar to pancreatic ductal adenocarcinoma. Mod Pathol 22: 651-659, 2009.

55. Simtniece Z, Vanags A, Strumfa I, Sperga M, Vasko E, Prieditis P, Trapencieris P and Gardovskis J: Morphological and immunohistochemical profile of pancreatic neuroendocrine neoplasms. Pol J Pathol 66: 176-194, 2015.

56. Weissmueller S, Manchado E, Saborowski M, Morris JP IV, Wagenblast E,DavisCA,Moon SH,Pfister NT, Tschaharganeh DF, Kitzing T, et al: Mutant p53 drives pancreatic cancer metastasis through cell-autonomous PDGF receptor $\beta$ signaling. Cell 157: 382-394, 2014

57. Morton JP, Timpson P, Karim SA, Ridgway RA, Athineos D, Doyle B, Jamieson NB, Oien KA, Lowy AM, Brunton VG, et al: Mutant p53 drives metastasis and overcomes growth arrest/senescence in pancreatic cancer. Proc Natl Acad Sci USA 107: 246-251, 2010.

58. Wolf D, Harris N and Rotter V: Reconstitution of p53 expression in a nonproducer $\mathrm{Ab}-\mathrm{MuLV}$-transformed cell line by transfection of a functional p53 gene. Cell 38: 119-126, 1984.

59. Muller PA, Vousden KH and Norman JC: p53 and its mutants in tumor cell migration and invasion. J Cell Biol 192: 209-218, 2011.

60. Freed-Pastor WA and Prives C: Mutant p53: One name, many proteins. Genes Dev 26: 1268-1286, 2012

61. Brosh R and Rotter V: When mutants gain new powers: News from the mutant p53 field. Nat Rev Cancer 9: 701-713, 2009.

62. Zhang C, Liu J, Liang Y, Wu R, Zhao Y, Hong X, Lin M, Yu H, Liu L, Levine AJ, et al: Tumour-associated mutant p53 drives the Warburg effect. Nat Commun 4: 2935, 2013. 
63. Yan W, Liu G, Scoumanne A and Chen X: Suppression of inhibitor of differentiation 2, a target of mutant p53, is required for gain-of-function mutations. Cancer Res 68: 6789-6796, 2008

64. Do PM, Varanasi L, Fan S, Li C, Kubacka I, Newman V, Chauhan K, Daniels SR, Boccetta M, Garrett MR, et al: Mutant p53 cooperates with ETS2 to promote etoposide resistance. Genes Dev 26: 830-845, 2012.

65. Yan W and Chen X: Identification of GRO1 as a critical determinant for mutant $\mathrm{p} 53$ gain of function. J Biol Chem 284 12178-12187, 2009.

66. Rosenfeldt MT, O'Prey J, Morton JP, Nixon C, MacKay G, Mrowinska A, Au A, Rai TS, Zheng L, Ridgway R, et al: P53 status determines the role of autophagy in pancreatic tumour development. Nature 504: 296-300, 2013.

67. Li Y and Prives C: Are interactions with p63 and p73 involved in mutant p53 gain of oncogenic function? Oncogene 26 2220-2225, 2007.

68. Di Agostino S, Strano S, Emiliozzi V, Zerbini V, Mottolese M, Sacchi A, Blandino G and Piaggio G: Gain of function of mutant p53: The mutant $\mathrm{p} 53 / \mathrm{NF}-\mathrm{Y}$ protein complex reveals an aberrant transcriptional mechanism of cell cycle regulation. Cancer Cell 10: 191-202, 2006

69. Fiorini C, Cordani M, Padroni C, Blandino G, Di Agostino S and Donadelli M: Mutant p53 stimulates chemoresistance of pancreatic adenocarcinoma cells to gemcitabine. Biochim Biophys Acta 1853: 89-100, 2015.

70. Song H, Hollstein M and Xu Y: p53 gain-of-function cancer mutants induce genetic instability by inactivating ATM. Nat Cell Biol 9: 573-580, 2007.

71. Restle A, Färber M, Baumann C, Böhringer M, Scheidtmann KH, Müller-Tidow C and Wiesmüller L: Dissecting the role of p53 phosphorylation in homologous recombination provides new clues for gain-of-function mutants. Nucleic Acids Res 36 $5362-5375,2008$.

72. Liu DP, Song $\mathrm{H}$ and $\mathrm{Xu} \mathrm{Y}$ : A common gain of function of p53 cancer mutants in inducing genetic instability. Oncogene 29 949-956, 2010.

73. Müller BF, Paulsen D and Deppert W: Specific binding of MAR/SAR DNA-elements by mutant p53. Oncogene 12 1941-1952, 1996.

74. Will K, Warnecke G, Wiesmüller L and Deppert W: Specific interaction of mutant p53 with regions of matrix attachment region DNA elements (MARs) with a high potential for base-unpairing. Proc Natl Acad Sci USA 95: 13681-13686, 1998.

75. Neilsen PM, Noll JE, Mattiske S, Bracken CP, Gregory PA, Schulz RB, Lim SP, Kumar R, Suetani RJ, Goodall GJ and Callen DF: Mutant p53 drives invasion in breast tumors through up-regulation of miR-155. Oncogene 32: 2992-3000, 2013.

76. Wang W, Cheng B, Miao L, Mei Y and Wu M: Mutant p53-R273H gains new function in sustained activation of EGFR signaling via suppressing miR-27a expression. Cell Death Dis 4 e 574, 2013.

77. Gonfloni S, Caputo V and Iannizzotto V: P63 in health and cancer. Int J Dev Biol 59: 87-93, 2015.

78. Flores ER, Sengupta S, Miller JB, Newman JJ, Bronson R, Crowley D, Yang A, McKeon F and Jacks T: Tumor predisposition in mice mutant for p63 and p73: Evidence for broader tumor suppressor functions for the p53 family. Cancer Cell 7: 363-373, 2005.

79. Keyes WM, Vogel H, Koster MI, Guo X, Qi Y, Petherbridge KM, Roop DR, Bradley A and Mills AA: P63 heterozygous mutant mice are not prone to spontaneous or chemically induced tumors. Proc Natl Acad Sci USA 103: 8435-8440, 2006.

80.Su X, Gi YJ, Chakravarti D, Chan IL, Zhang A, Xia X, Tsai KY and Flores ER: TAp63 is a master transcriptional regulator of lipid and glucose metabolism. Cell Metab 16 511-525, 2012.

81. Giacobbe A, Bongiorno-Borbone L, Bernassola F, Terrinoni A, Markert EK, Levine AJ, Feng Z, Agostini M, Zolla L, Agrò AF, et al: $\mathrm{P} 63$ regulates glutaminase 2 expression. Cell Cycle 12: 1395-1405, 2013.

82.Liu G and Chen X: The ferredoxin reductase gene is regulated by the 53 family and sensitizes cells to oxidative stress-induced apoptosis. Oncogene 21: 7195-7204, 2002.

83. Suh EK, Yang A, Kettenbach A, Bamberger C, Michaelis AH, Zhu Z, Elvin JA, Bronson RT, Crum CP and McKeon F: P63 protects the female germ line during meiotic arrest. Nature 444: 624-628, 2006.
84. Su X, Napoli M, Abbas HA, Venkatanarayan A, Bui NHB, Coarfa C, Gi YJ, Kittrell F, Gunaratne PH, Medina D, et al: TAp63 suppresses mammary tumorigenesis through regulation of the Hippo pathway. Oncogene 36: 2377-2393, 2017.

85. Urist MJ, Di Como CJ, Lu M-L, Charytonowicz E, Verbel D, Crum CP, Ince TA, McKeon FD and Cordon-Cardo C: Loss of p63 expression is associated with tumor progression in bladder cancer. Am J Pathol 161: 1199-1206, 2002.

86. Barbieri CE, Tang LJ, Brown KA and Pietenpol JA: Loss of p63 leads to increased cell migration and up-regulation of genes involved in invasion and metastasis. Cancer Res 66: 7589-7597, 2006

87. Adorno M, Cordenonsi M, Montagner M, Dupont S, Wong C, Hann B, Solari A, Bobisse S, Rondina MB, Guzzardo V, et al: A mutant-p53/Smad complex opposes p63 to empower TGFbeta-induced metastasis. Cell 137: 87-98, 2009.

88. Tan EH, Morton JP, Timpson P, Tucci P, Melino G, Flores ER Sansom OJ, Vousden KH and Muller PA: Functions of TAp63 and p53 in restraining the development of metastatic cancer. Oncogene 33: 3325-3333, 2014.

89. Lin YL, Sengupta S, Gurdziel K, Bell GW, Jacks T and Flores ER: p63 and p73 transcriptionally regulate genes involved in DNA repair. PLoS Genet 5: e1000680, 2009.

90. Marine JC and Berx G: Transforming growth factor-beta and mutant p53 conspire to induce metastasis by antagonizing p63 A (ternary) complex affair. Breast Cancer Res 11: 304, 2009.

91. Neilsen PM, Noll JE, Suetani RJ, Schulz RB, Al-ejeh F, Evdokiou A, Lane DP and Callen DF: Mutant p53 uses p63 as a molecular chaperone to alter gene expression and induce a pro-invasive secretome. Oncotarget 2: 1203-1217, 2011

92. Viticchiè G, Agostini M, Lena AM, Mancini M, Zhou H, Zolla L, Dinsdale D, Saintigny G, Melino G and Candi E: p63 supports aerobic respiration through hexokinase II. Proc Nat Acad Sci USA 112: 11577-11582, 2015.

93. Yan W and Chen X: GPX2, a direct target of p63, inhibits oxidative stress-induced apoptosis in a p53-dependent manner. J Biol Chem 281: 7856-7862, 2006

94. Senoo M, Pinto F, Crum CP and McKeon F: p63 is essential for the proliferative potential of stem cells in stratified epithelia. Cell 129: 523-536, 2007

95. Pignon JC, Grisanzio C, Geng Y, Song J, Shivdasani RA and Signoretti S: P63-expressing cells are the stem cells of developing prostate, bladder, and colorectal epithelia. Proc Natl Acad Sci USA 110: 8105-8110, 2013

96. Rocco JW, Leong CO, Kuperwasser N, DeYoung MP and Ellisen LW: P63 mediates survival in squamous cell carcinoma by suppression of p73-dependent apoptosis. Cancer Cell 9: 45-56, 2006

97. Di Como CJ, Urist MJ, Babayan I, Drobnjak M, Hedvat CV, Teruya-Feldstein J, Pohar K, Hoos A and Cordon-Cardo C: P63 expression profiles in human normal and tumor tissues. Clin Cancer Res 8: 494-501, 2002.

98. Deyoung MP and Ellisen LW: P63 and P73 in human cancer: Defining the network. Oncogene 26: 5169-5183, 2007.

99. Leong CO, Vidnovic N, DeYoung MP, Sgroi D and Ellisen LW: The p63/p73 network mediates chemosensitivity to cisplatin in a biologically defined subset of primary breast cancers. J Clin Invest 117: 1370-1380, 2007.

100. Fukushima H, Koga F, Kawakami S, Fujii Y, Yoshida S, Ratovitski E, Trink B and Kihara K: Loss of DeltaNp63alpha promotes invasion of urothelial carcinomas via $\mathrm{N}$-cadherin/Src homology and collagen/extracellular signal-regulated kinase pathway. Cancer Res 69: 9263-9270, 2009.

101. Yang X, Lu H, Yan B, Romano RA, Bian Y, Friedman J, Duggal P, Allen C, Chuang R, Ehsanian R, et al: $\Delta$ Np63 versatilely regulates a broad NF- $\mathrm{KB}$ gene program and promotes squamous epithelial proliferation, migration, and inflammation. Cancer Res 71: 3688-3700, 2011.

102. Basturk O, Khanani F, Sarkar F, Levi E, Cheng JD and Adsay NV: DeltaNp63 expression in pancreas and pancreatic neoplasia. Mod Pathol 18: 1193-1198, 2005.

103. Komori T, Yagi H, Nomura S, Yamaguchi A, Sasaki K, Deguchi K, Shimizu Y, Bronson RT, Gao YH, Inada M, et al: Targeted disruption of Cbfa1 results in a complete lack of bone formation owing to maturational arrest of osteoblasts. Cell 89: 755-764, 1997.

104. Otto F, Thornell AP, Crompton T, Denzel A, Gilmour KC, Rosewell IR, Stamp GW, Beddington RS, Mundlos S, Olsen BR, et al: Cbfa1, a candidate gene for cleidocranial dysplasia syndrome, is essential for osteoblast differentiation and bone development. Cell 89: 765-771, 1997. 
105. Barnes GL, Javed A, Waller SM, Kamal MH, Hebert KE, Hassan MQ, Bellahcene A, Van Wijnen AJ, Young MF, Lian JB, et al: Osteoblast-related transcription factors Runx2 (Cbfa1/AML3) and MSX2 mediate the expression of bone sialoprotein in human metastatic breast cancer cells. Cancer Res 63 : 2631-2637, 2003.

106. Akech J, Wixted JJ, Bedard K, van der Deen M, Hussain S, Guise TA, van Wijnen AJ, Stein JL, Languino LR, Altieri DC, et al: Runx2 association with progression of prostate cancer in patients: Mechanisms mediating bone osteolysis and osteoblastic metastatic lesions. Oncogene 29: 811-821, 2010.

107. Pratap J, Javed A, Languino LR, van Wijnen AJ, Stein JL, Stein GS and Lian JB: The Runx 2 osteogenic transcription factor regulates matrix metalloproteinase 9 in bone metastatic cancer cells and controls cell invasion. Mol Cell Biol 25 8581-8591, 2005.

108. Kuo Y, Zaidi SK, Gornostaeva S, Komori T, Stein GS and Castilla LH: Runx2 induces acute myeloid leukemia in cooperation with Cbfbeta-SMMHC in mice. Blood 113: 3323-3333, 2019.

109. Kayed H, Jiang X, Keleg S, Jesnowski R, Giese T, Berger M, Esposito I, Löhr M, Friess H and Kleeff J: Regulation and functional role of the Runt-related transcription factor- 2 in pancreatic cancer. Br J Cancer 97: 1106-1115, 2007.

110. Boregowda R, Olabisi O, Abushahba W, Jeong B, Haenssen K, Chen W, Chekmareva M, Lasfar A, Foran DJ, Goydos JS and Cohen-Solal KA: RUNX2 is overexpressed in melanoma cells and mediates their migration and invasion. Cancer Lett 348: 61-70, 2014.

111. Zelzer E, Glotzer DJ, Hartmann C, Thomas D, Fukai N, Soker S and Olsen BR: Tissue specific regulation of VEGF expression during bone development requires Cbfa1/Runx2. Mech Dev 106: 97-106, 2001

112. Ozaki T, Wu D, Sugimoto H, Nagase $H$ and Nakagawara A: Runt-related transcription factor 2 (RUNX2) inhibits p53-dependent apoptosis through the collaboration with HDAC6 in response to DNA damage. Cell Death Dis 4: e610, 2013.

113. Sugimoto H, Nakamura M, Yoda H, Hiraoka K, Shinohara K, Sang M,Fujiwara K, Shimozato O, Nagase Hand Ozaki T: Silencing of RUNX2 enhances gemcitabine sensitivity of p53-deficient human pancreatic cancer AsPC-1 cells through the stimulation of TAp63-mediated cell death. Cell Death Dis 6: e1914, 2015.

114. Ozaki T, Sugimoto H, Nakamura M, Hiraoka K, Yoda $H$, Sang M, Fujiwara $\mathrm{K}$ and Nagase $\mathrm{H}$ : Runt-related transcription factor 2 attenuates the transcriptional activity as well as DNA damage-mediated induction of pro-apoptotic TAp73 to regulate chemosensitivity. FEBS J 282: 114-128, 2015

115. Stojanovic N, Hassan Z, Wirth M, Wenzel P, Beyer M, Schäfer C, Brand P, Kroemer A, Stauber RH, Schmid RM, et al: HDAC1 and HDAC2 integrate the expression of p53 mutants in pancreatic cancer. Oncogene 36: 1804-1815, 2017.

116. Grant S, Easley C and Kirkpatrick P: Vorinostat. Nat Rev Drug Discov 6: 21-22, 2007.

117. Gryder B, Sodji Q and Oyelere A: Targeted cancer therapy: Giving histone deacetylase inhibitors all they need to succeed. Futur Med Chem 4: 505-524, 2012.

118. Ogata T, Nakamura M, Sang M, Yoda H, Hiraoka K, Yin D, Sang M, Shimozato O and Ozaki T: Depletion of runt-related transcription factor 2 (RUNX2 ) enhances SAHA sensitivity of p53-mutated pancreatic cancer cells through the regulation of mutant p53 and TAp63. PLoS One 12: e0179884, 2017.

119. Ozaki T, Nakamura M, Ogata T, Sang M, Yoda H, Hiraoka K, Sang M and Shimozato O: Depletion of pro-oncogenic RUNX2 enhances gemcitabine (GEM) sensitivity of p53-mutated pancreatic cancer Panc-1 cells through the induction of pro-apoptotic TAp63. Oncotarget 7: 71937-71950, 2016.

120. Nakaya N, Ishigaki Y, Nakajima H, Murakami M, Shimasaki T, Takata T, Ozaki M, Dusetti NJ, Iovanna JL and Motoo Y: Meaning of tumor protein 53-induced nuclear protein 1 in the molecular mechanism of gemcitabine sensitivity. Mol Clin Oncol 1: 100-104, 2013.

121. Irwin M, Marin MC, Phillips AC, Seelan RS, Smith DI, Liu W, Flores ER, Tsai KY, Jacks T, Vousden KH and Kaelin WG Jr: Role for the p53 homologue p73 in E2F-1-induced apoptosis. Nature 407: 645-648, 2000 .

122. Stiewe T and Putzer BM: Role of the p53-homologue p73 in E2F1-induced apoptosis. Nat Genet 26: 464-469, 2000.

123. Xia X, Zhang K, Luo G, Cen G, Cao J, Huang K and Qiu Z: Downregulation of miR-301a-3p sensitizes pancreatic cancer cells to gemcitabine treatment via PTEN. Am J Transl Res 9: 1886-1895, 2017.
124. Luo G, Xia X, Wang X, Zhang K, Cao J, Jiang T, Zhao Q and Qiu Z: miR-301a plays a pivotal role in hypoxia-induced gemcitabine resistance in pancreatic cancer. Exp Cell Res 369: $120-128,2018$

125. Lee EJ, Gusev Y, Jiang J, Nuovo GJ, Lerner MR, Frankel WL, Morgan DL, Postier RG, Brackett DJ and Schmittgen TD: Expression profiling identifies microRNA signature in pancreatic cancer. Int J Cancer 120: 1046-1054, 2007.

126. Xia X, Zhang K, Cen G, Jiang T, Cao J, Huang K, Huang C, Zhao $Q$ and Qiu Z: MicroRNA-301a-3p promotes pancreatic cancer progression via negative regulation of SMAD4. Oncotarget 6: 21046-21063, 2015.

127. Rohwer N and Cramer T: Hypoxia-mediated drug resistance: Novel insights on the functional interaction of HIFs and cell death pathways. Drug Resist Updat 14: 191-201, 2011.

128. Nakazawa MS, Keith B and Simon MC: Oxygen availability and metabolic adaptations. Nat Rev Cancer 16: 663-673, 2016.

129. Rankin EB and Giaccia AJ: Hypoxic control of metastasis. Science 352: 175-180, 2016.

130. Shukla SK, Purohit V, Mehla K, Gunda V, Chaika NV, Vernucci E, King RJ, Abrego J, Goode GD, Dasgupta A, et al: MUC1 and HIF-1alpha signaling crosstalk induces anabolic glucose metabolism to impart gemcitabine resistance to pancreatic cancer. Cancer Cell 32: 71-87.e7, 2017.

131. Comerford KM, Wallace TJ, Karhausen J, Louis NA, Montalto MC and Colgan SP: Hypoxia-inducible factor-1-dependent regulation of the multidrug resistance (MDR1) gene. Cancer Res 62: 3387-3394, 2002.

132. He X, Wang J, Wei W, Shi M, Xin B, Zhang T and Shen X: Hypoxia regulates ABCG 2 activity through the activivation of ERK1/2/HIF- $1 \alpha$ and contributes to chemoresistance in pancreatic cancer cells. Cancer Biol Ther 17: 188-198, 2016.

133. Choi W, Shah JB, Tran M, Svatek R, Marquis L, Lee I, Yu D, Adam L, Wen S, Shen Y, et al: p63 expression defines a lethal subset of muscle-invasive bladder cancers. PLoS One 7: e30206, 2012.

134. Dang TT, Westcott JM, Maine EA, Kanchwala M, Xing C and Pearson GW: $\triangle \mathrm{Np} 63 \alpha$ induces the expression of FAT2 and slug to promote tumor invasion. Oncotarget 7: 28592-28611, 2016.

135. Melino G, Bernassola F, Ranalli M, Yee K, Zong WX, Corazzari M, Knight RA, Green DR, Thompson C and Vousden KH: p75 induces apoptosis via PUMA transactivation and Bax mitochondrial translocation. J Biol Chem 279: 8076-8083, 2004.

136. John K, Alla V, Meier C and Pützer BM: GRAMD4 mimics p53 and mediates the apoptotic function of p73 at mitochondria. Cell Death Differ 18: 874-886, 2011.

137. Deng Y and Wu X: Peg3/Pw1 promotes p53-mediated apoptosis by inducing Bax translocation from cytosol to mitochondria. Proc Natl Acad Sci USA 97: 12050-12055, 2000.

138. Stantic M, Sakil HAM, Zirath H, Fang T, Sanz G, Fernandez-Woodbridge A, Marin A, Susanto E, Mak TW, Arsenian Henriksson M and Wilhelm MT: TAp73 suppresses tumor angiogenesis through repression of proangiogenic cytokines and HIF-1 $\alpha$ activity. Proc Natl Acad Sci USA 112: 220-225, 2015

139. Amelio I, Inoue S, Markert EK, Levine AJ, Knight RA, Mak TW and Melino G: TAp73 opposes tumor angiogenesis by promoting hypoxia-inducible factor $1 \alpha$ degradation. Proc Natl Acad Sci USA 112: 226-231, 2015.

140. Dulloo I, Hooi PB and Sabapathy K: Hypoxia-induced DNp73 stabilization regulates Vegf-A expression and tumor angiogenesis similar to TAp73. Cell Cycle 14: 3533-3539, 2015.

141. Dulloo I, Phang BH, Othman R, Tan SY, Vijayaraghavan A, Goh LK, Martin-Lopez M, Marques MM, Li CW, Wang de Y, et al: Hypoxia-inducible TAp73 supports tumorigenesis by regulating the angiogenic transcriptome. Nat Cell Biol 17: 511-523, 2015.

142. Fernandez-Alonso R, Martin-Lopez M, Gonzalez-Cano L, Garcia S, Castrillo F, Diez-Prieto I, Fernandez-Corona A, Lorenzo-Marcos ME, Li X, Claesson-Welsh L, et al: p73 is required for endothelial cell differentiation, migration and the formation of vascular networks regulating VEGF and TGF $\beta$ signaling. Cell Death Differ 22: 1287-1299, 2015.

143. Tomasini R, Tsuchihara K, Wilhelm M, Fujitani M, Rufini A, Cheung CC, Khan F, Itie-Youten A, Wakeham A, Tsao MS, et al: TAp73 knockout shows genomic instability with infertility and tumor suppressor functions. Genes Dev 22: 2677-2691, 2008 
144. Tomasini R, Tsuchihara K, Tsuda C, Lau SK, Wilhelm M, Ruffini A, Tsao MS, Iovanna JL, Jurisicova A, Melino G and Mak TW: TAp73 regulates the spindle assembly checkpoint by modulating BubR1 activity. Proc Natl Acad Sci USA 106: 797-802, 2009.

145. Vikhreva P, Petrova V, Gokbulut T, Pestlikis I, Mancini M, Di Daniele N, Knight RA and Melino G: TAp73 upregulates IL-1 $\beta$ in cancer cells: Potential biomarker in lung and breast cancer? Biochem Biophys Res Commun 482: 498-505, 2017.

146. Galtsidis S, Logotheti S, Pavlopoulou A, Zampetidis CP Papachristopoulou G, Scorilas A, Vojtesek B, Gorgoulis V and Zoumpourlis V: Unravelling a p73-regulated network: The role of a novel p73-dependent target, MIR3158, in cancer cell migration and invasiveness. Cancer Lett 388: 96-106, 2017.

147. Ory B, Ramsey MR, Wilson C, Vadysirisack DD Forster N, Rocco JW, Rothenberg SM and Ellisen LW: A microRNA-dependent program controls p53-independent survival and chemosensitivity in human and murine squamous cell carcinoma. J Clin Invest 121: 809-820, 2011.

148. Bardeesy N, Cheng K, Berger JH, Chu GC, Pahler J, Olson P, Hezel AF, Horner J, Lauwers GY, Hanahan D and DePinho RA: Smad4 is dispensable for normal pancreas development yet critical in progression and tumor biology of pancreas cancer. Genes Dev 20: 3130-3146, 2006.

149. de la Fuente M, Jones MC, Santander-Ortega MJ, Mirenska A, Marimuthu P, Uchegbu I and Schätzlein A: A nano-enabled cancer-specific ITCH RNAi chemotherapy booster for pancreatic cancer. Nanomedicine 11: 369-377, 2015.

150. Plunkett W, Huang P, Xu YZ, Heinemann V, Grunewald R and Gandhi V: Gemcitabine: Metabolism, mechanisms of action, and self-potentiation. Semin Oncol 22 (4 Suppl 11): S3-S10, 1995.

151. Huang P, Chubb S, Hertel L, Grindey G and Plunkett W: Action of 2',2'-difluorodeoxycytidine on DNA synthesis. Cancer Res 51: 6110-6117, 1991

152. Achanta G, Pelicano H, Feng L, Plunkett W and Huang P. Interaction of p53 and DNA-PK in response to nucleoside analogues: Potential role as a sensor complex for DNA damage. Cancer Res 61: 8723-8729, 2001.

153. Galmarini CM, Clarke ML, Falette N, Puisieux A, Mackey JR and Dumontet C: Expression of a non-functional p53 affects the sensitivity of cancer cells to gemcitabine. Int J Cancer 97: 439-445, 2002.

154.Zeng X, Chen L, Jost CA, Maya R, Keller D, Wang X, Kaelin WG Jr, Oren M, Chen J and Lu H: MDM2 suppresses p73 function without promoting p73 degradation. Mol Cell Biol 19: 3257-3266, 1999

155. Su J, Zhou X, Yin X, Wang L, Zhao Z, Hou Y, Zheng N, Xia J and Wang Z: The effects of curcumin on proliferation, apoptosis, invasion, and NEDD4 expression in pancreatic cancer. Biochem Pharmacol 140: 28-40, 2017.

156. Yang SH, Lee JC, Guo JC, Kuo SH, Tien YW, Kuo TC, Cheng AL and Yeh KH: Association of MDM2 expression with shorter progression-free survival and overall survival in patients with advanced pancreatic cancer treated with gemcitabine-based chemotherapy. PLoS One 12: e0180628, 2017.

157. Azmi AS, Aboukameel A, Banerjee S, Wang Z, Mohammad M, Wu J, Wang S, Yang D, Philip PA, Sarkar FH and Mohammad RM: MDM2 inhibitor MI-319 in combination with cisplatin is an effective treatment for pancreatic cancer independent of p53 function. Eur J Cancer 46: 1122-1131, 2010.

158. Azmi AS, Ali S, Banerjee S, Bao B, Maitah M, Padhye S, Philip PA, Mohammad RM and Sarkar FH: Network modeling of CDF treated pancreatic cancer cells reveals a novel c-myc-p73 dependent apoptotic mechanism. Am J Transl Res 3: 374-382, 2011.

159. Hamilton G, Abraham A, Morton J, Sampson O, Pefani D, Khoronenkova S, Grawenda A, Papaspyropoulos A, Jamieson N McKay C, et al: AKT regulates NPM dependent ARF localization and p53mut stability in tumors. Oncotarget 5: 6142-6167, 2014

160. Bid HK, Roberts RD, Cam M, Audino A, Kurmasheva RT, Lin J, Houghton PJ and Cam $\mathrm{H}: \Delta \mathrm{Np} 63$ promotes pediatric neuroblastoma and osteosarcoma by regulating tumor angiogenesis. Cancer Res 74: 320-329, 2014.
161. Zhang Y,Zeng SX, Hao Q and Lu H: Monitoring p53 by MDM2 and MDMX is required for endocrine pancreas development and function in a spatio-temporal manner. Dev Biol 423: 34-45, 2017

162. Vassilev LT, Vu BT, Craves B, Carvajal D, Podlaski F, Filipovic Z, Kong N, Kammlott U, Lukacs C, Klein C, et al: In vivo activation of the 53 pathway by small-molecule antagonists of MDM2. Science 303: 844-848, 2004.

163. Grasberger BL, Lu T, Schubert C, Parks DJ, Carver TE, Koblish HK, Cummings MD, LaFrance LV, Milkiewicz KL, Calvo RR, et al: Discovery and cocrystal structure of benzodiazepinedione HDM2 antagonists that activate p53 in cells. J Med Chem 48: 909-912, 2005.

164. Issaeva N, Bozko P, Enge M, Protopopova M, Verhoef LGGC, Masucci M, Pramanik A and Selivanova G: Small molecule RITA binds to p53, blocks p53-HDM-2 interaction and activates p53 function in tumors. Nat Med 10: 1321-1328, 2004.

165. Yu X, Vazquez A, Levine AJ and Carpizo DR: Allele-specific p53 mutant reactivation. Cancer Cell 21: 614-625, 2012

166. Lambert JMR, Moshfegh A, Hainaut P, Wiman KG and Bykov VJ: Mutant p53 reactivation by PRIMA-1MET induces multiple signaling pathways converging on apoptosis. Oncogene 29: 1329-1338, 2010.

167. Tang X, Zhu Y, Han L, Kim AL, Kopelovich L, Bickers DR and Athar M: CP-31398 restores mutant p53 tumor suppressor function and inhibits UVB-induced skin carcinogenesis in mice. J Clin Invest 117: 3753-3764, 2007.

168. Bykov VJN, Issaeva N, Shilov A, Hultcrantz M, Pugacheva E, Chumakov P, Bergman J, Wiman KG and Selivanova G: Restoration of the tumor suppressor function to mutant $\mathrm{p} 53$ by a low-molecular-weight compound. Nat Med 8: 282-288, 2002.

169. Li D, Marchenko ND, Schulz R, Fischer V, Velasco-Hernandez T, Talos F and Moll UM: Functional inactivation of endogenous MDM2 and CHIP by HSP90 causes aberrant stabilization of mutant p53 in human cancer cells. Mol Cancer Res 9: 577-588, 2011

170. Li D, Marchenko ND and Moll UM: SAHA shows preferential cytotoxicity in mutant p53 cancer cells by destabilizing mutant p53 through inhibition of the HDAC6-Hsp90 chaperone axis. Cell Death Differ 18: 1904-1913, 2011.

171. Liu J, Zhang C and Feng Z: Tumor suppressor p53 and its gain-of-function mutants in cancer. Acta Biochim Biophys Sin (Shanghai) 46: 170-179, 2014

172. Stindt MH, Muller PAJ, Ludwig RL, Kehrloesser S, Dötsch V and Vousden KH: Functional interplay between MDM2, p63/p73 and mutant p53. Oncogene 34: 4300-4310, 2015.

173. Ludes-Meyers JH, Subler MA, Shivakumar CV, Munoz RM, Jiang P, Bigger JE, Brown DR, Deb SP and Deb S: Transcriptional activation of the human epidermal growth factor receptor promoter by human p53. Mol Cell Biol 16: 6009-6019, 1996.

174. Weisz L, Zalcenstein A, Stambolsky P, Cohen Y, Goldfinger N, Oren $\mathrm{M}$ and Rotter V: Transactivation of the EGR1 gene contributes to mutant p53 gain of function. Cancer Res 64: 8318-8327, 2004.

175. Scian MJ, Stagliano KER, Anderson MAE, Hassan S, Bowman M, Miles MF, Deb SP and Deb S: Tumor-derived p53 mutants induce NF-kappaB2 gene expression. Mol Cell Biol 25: 10097-10110, 2005.

176. Strano S, Dell'Orso S, Di Agostino S, Fontemaggi G, Sacchi A and Blandino G: Mutant p53: An oncogenic transcription factor. Oncogene 26: 2212-2219, 2007.

177. Wang Q, Selth LA and Callen DF: MiR-766 induces p53 accumulation and G2/M arrest by directly targeting MDM4. Oncotarget 8: 29914-29924, 2017.

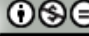

This work is licensed under a Creative Commons Attribution-NonCommercial-NoDerivatives 4.0 International (CC BY-NC-ND 4.0) License. 